\title{
Bioprospecting Fungal Glycosyl Hydrolases: Multi-locus Phylogenetic Analysis and Enzyme Activity Profiling for Enhanced Biomass Valorization
}

\section{Meenal Rastogi}

Amity University

Smriti Shrivastava ( $D$ shrivastava.smriti@gmail.com )

Amity University https://orcid.org/0000-0002-5382-5378

\section{Pratyoosh Shukla}

Banaras Hindu University Department of Bio-Technology

\section{Original article}

Keywords: Xylanases, Aspergillus species, Saccharification, Lignocelluloses, Molecular phylogeny, Bioprospecting

Posted Date: December 30th, 2020

DOI: https://doi.org/10.21203/rs.3.rs-135571/v1

License: (c) (i) This work is licensed under a Creative Commons Attribution 4.0 International License. Read Full License 


\section{Abstract}

Lignocelluloses comprise of celluloses and hemicelluloses which can be effectively depolymerized to obtain fermentable sugars using diverse microbial enzymes, for subsequent conversion to various value-added products. Present study reports the bioprospecting of industrially significant microorganisms and their characterization to attain xylanases with high catalytic efficiency. Four potential xylanolytic fungi were identified through distinct primary and secondary screening process of 294 isolates from samples containing plant degrades. Morphological characterization and multigene analysis (ITS rDNA, 18S rDNA, nLSU rDNA, $\beta$-tubulin and actin gene) confirmed them Aspergillus niger AUMS56, Aspergillus tubingensis AUMS60, Aspergillus niger AUMS64 and Aspergillus fumigatus AUKEMS24 and their crude xylanase activities through submerged fermentation using corncob were 18.9, 32.29, 30.68 and $15.82 \mathrm{U} \mathrm{ml}^{-1}$, respectively. AUMS60 and AUMS64 have highest catalytic activity of $1429 \mathrm{U} \mathrm{g}^{-1}$ and $1243 \mathrm{U} \mathrm{g} \mathrm{g}^{-1}$, respectively, all having $\mathrm{pH}$ and temperature optima of 6.0 and $60^{\circ} \mathrm{C}$ respectively, where AUMS60 produced single xylanase (Xyn60;36 kDa) and AUMS64 secreted 2 probable isozymes (Xyn64A and Xyn64B; 33.4 and $19.8 \mathrm{kDa}$ ). Maximum saccharification efficiency of AUMS60 and AUMS64 were 51.1\% (13 h) and 52.2\% (24 h) showing enhanced catalytic activity with various cations. Present research reports potential xylanases from indigenous fungi, providing opportunity for development of bio-catalysts concoction (novelty established) for enhanced saccharification of complex lignocelluloses finding specific industrial applications for production of value-added components.

\section{Key Points}

- Crude activity of Xyn60 and Xyn64A, B as $1429 \mathrm{U} \mathrm{g}^{-1}$ and $1243 \mathrm{U} \mathrm{g}^{-1}$

- Physico-chemical characterization of Xyn60, Xyn64A and Xyn64B

- Saccharification efficiency of Xyn60, Xyn64A and Xyn64B (all above 50\%)

\section{Introduction}

Growing concerns over global warming and hike in fuel prices has necessitated usage of lignocellulosic biomass (most abundant natural biopolymer) as a renewable and eco-friendly source of current fuel platform. There is a strong impetus worldwide, for usage of biofuels that are economical and sustainable (Rastogi and Shrivastava 2017). Holocelluloses (cellulose and all of the hemicellulose) forms major fraction of lignocelluloses along with lignin which can be ideally hydrolyzed to monosaccharides for effective conversion to various value-added products. Traditional thermochemical methods utilized for degradation of lignocelluloses typically generate toxic by-products, therefore emphasis is laid on enzymatic saccharification considering the cost and yield in the biorefineries (Varghese et al. 2017; Sunkar et al. 2020). Lignocellulosic biomass is naturally degraded by diverse glycosyl hydrolases (GHs) producing microorganisms that can be utilized for several industrial as well as biotechnological applications. Cellulases, xylanases, lipases, pectinases, proteases and ligninolytic enzymes are few of the enzymes being utilized for the improvement of microbial and enzymatic processes for degradation of lignocelluloses (Rastogi and Shrivastava 2020).

Xylanases are ubiquitously found in nature produced by a variety of organisms but fungi secrete much higher levels of xylanases than other microbes in addition to several auxiliary enzymes required for the degradation of the substituted xylan (Polizeli et al. 2005). Xylanase cleaves $\beta-1,4$ glycosidic backbone of xylan (major hemicellulosic fraction) generally releasing xylose and xylobiose such as xylo-oligosaccharides as end products (Shrivastava 2020). In the last few decades, microbial xylanolytic enzymes have demonstrated a tremendous biotechnological potential in various fields apart from bioenergy production, including food for improving dough elasticity, animal husbandry for boosting the weight of chicks, clarifying juices for degumming of fibers, bread making, pre-bleaching of Kraft pulp, deinking of 
waste newspapers and wine making (Chadha et al. 2019; Rastogi and Shrivastava 2020). Enzymatic saccharification of lignocellulosic biomass is a feasible alternative to physico-chemical treatment but its usage is limited owing to the high cost of enzymes. On the other hand, a vast array of indigenous microorganisms can be exploited for production of desirable glycosyl hydrolases via submerged (SmF) or solid-state fermentation (SSF) by substituting purified xylan with lignocellulosic biomass as substrate for providing the necessary nutrients for the microbial growth and the induction of the enzymatic production (Sunkar et al. 2020). SmF system accounts nearly for $90 \%$ of total xylanase produced worldwide (Polizeli et al. 2005) and is considered more flexible for allowing large-scale fermentations (Taddia et al. 2020).

Filamentous fungi, such as Aspergillus, easily adapt for cultivation on solid substrates due to simulation of lignocelluloses to their natural habitat and hence deliberated as good producers of hydrolytic enzymes for holocellulose degradation (Dias et al. 2018). Presently, the usage of acidic and alkaline xylanases in industries is compromised due to the environmental impact and high energy costs while neutral and weak acidic enzymes with high shelf life are gaining popularity due to reduced energy and expenditure input for their production and functions (Guo et al. 2012). At industrial scale, thermostable enzymes (operating at $45-100^{\circ} \mathrm{C}$ ) not only improve enzyme robustness and enhance higher mass transfer and reaction rates decreasing the amount of enzyme required, but also reduce viscosity to increase the solubility of reactants and products, reduce risk of contamination and improve hydrolytic performance due to long half-lives at high temperatures (Bhalla et al. 2013; Bibra et al. 2018). Therefore, scientists are always exploring new microbial sources having higher activities with novel characteristics to improve efficiency for biomass valorization. Although a plethora of cellulo-xylanolytic strains have been reported, they are far from fulfilling our needs.

Present investigation reports bioprospecting of potential microorganisms for production of industrially significant xylanases with high catalytic activities, multi-locus phylogenetic analysis of selective organisms and partial profiling of xylanase enzyme activities for enhanced biomass valorization. These organisms were isolated from diverse waste residues rich in plant debris, through screening on enrichment media and characterized through morphological/physiological characteristics and multigene analysis (internal transcribed spacer (ITS) rDNA, 18S small subunit rDNA, 28S large subunit (nLSU) rDNA, $\beta$-tubulin and actin gene sequences). Two isolates selected for further studies AUMS60 (Aspergillus tubingensis) and AUMS64 (Aspergillus niger) were investigated on production and profiling of potential extracellular xylanase from them namely Xyn60, Xyn64A and Xyn64B. Profiling of physicochemical characteristics of theses enzymes suggested their industrial significance. Effect of metal ions, $\mathrm{pH}$ and temperature optima and stability suggests great catalytic potential of these enzymes.

\section{Materials And Methods}

\section{Agro-residues, chemicals and sample collection}

Agro-residues obtained from local farms were washed thoroughly, followed by oven drying and grinding to obtain particles of uniform size $1 \mathrm{~mm}$, to be used as carbon source during screening and fermentation process. Xylose (Sigma, USA), Oat spelts xylan, birchwood xylan, carboxymethyl cellulose (CMC), bovine serum albumin (BSA) and dinitrosalicylic acid (DNSA) were procured from HiMedia Laboratories Ltd. Mumbai, India. All the other media, chemicals, salts and reagents used were of analytical grade (Sigma-Aldrich, St. Louis, MO, USA; HiMedia, Mumbai, India; and Merck \& Co., Inc.). Optical compound microscope (Make-Magnus MLX-M) was used for microscopic analysis.

Samples were collected aseptically in soil rich in decaying plant matter and garbage waste from different locations of Noida and Delhi, India such as Okhla Bird Sanctuary $\left(28.5514^{\circ} \mathrm{N}, 77.3185^{\circ} \mathrm{E}\right)$, Challera $\left(28.5545^{\circ} \mathrm{N}, 77.3372^{\circ} \mathrm{E}\right)$ and Tajpur Pahari $\left(28.4948^{\circ} \mathrm{N}, 77.3059^{\circ} \mathrm{E}\right)$ and stored at $4^{\circ} \mathrm{C}$ until further study. 


\section{Isolation and screening of GHs producing microorganisms}

Serially diluted samples inoculated on nutrient agar (NA) and potato dextrose agar (PDA, $50 \mu \mathrm{g} \mathrm{ml}^{-1}$ ampicillin) plates, were incubated at $20-60^{\circ} \mathrm{C}$ for up to $72 \mathrm{~h}$ for isolating indigenous glycoside hydrolase producing strains. Isolates were sub-cultured and stored at $4^{\circ} \mathrm{C}$ and as glycerol stocks. Czapek-Dox mineral salt agar medium and Remazol brilliant blue xylan supplemented medium was utilized for screening of cellulolytic (Teather and Wood, 1982) and xylanolytic (Shrivastava et al. 2011) microorganisms, respectively.

\section{Screening through enrichment media and determination of xylanase and endoglucanase activity}

Enrichment medium (Potato dextrose broth supplemented with 1\% corn cob; agricultural residue; $\mathrm{pH}$ 5.5) was inoculated with pre-inoculum $\left(10^{6} \mathrm{spores} / \mathrm{ml}\right)$. Extracellular enzymes were produced through medium containing $\left(\mathrm{g} \mathrm{I}^{-1}\right)$ yeast extract (5), $\mathrm{KH}_{2} \mathrm{PO}_{4}(1)$ and $\mathrm{MgSO}_{4} .7 \mathrm{H}_{2} \mathrm{O}(0.5)$ supplemented with $2 \%(\mathrm{w} / \mathrm{v})$ corn cob ( $\left.\mathrm{pH} 5.5\right)$ at $40^{\circ} \mathrm{C}$ in a rotary shaker at $100 \mathrm{rpm}$ for 10-12 days, with enzyme activity of cell free extract determined at interval of $24 \mathrm{~h}$.

Xylanase activity was determined by monitoring the production of reducing sugars by 3,5-dinitrosalicylic acid (DNS) method (Miller 1959) with minor modifications using xylose as standard according to Bailey et al. (1992). One unit of xylanase activity was defined as the amount of enzyme that catalyzes the release of $1 \mu \mathrm{mol}$ of xylose equivalent per minute under defined assay conditions. CMCase activity was determined according to Ghose (1987), with 1\% CMC as substrate. One unit of CMCase activity was defined as the amount of enzyme that releases $1 \mu \mathrm{mol}$ of glucose per $\mathrm{ml}$ per minute.

\section{Identification of fungal isolates}

Xylanolytic and cellulolytic microbial strains were examined microscopically using Lactophenol cotton blue (Leck 1999) and Grams stain (Bartholomew and Mittwer 1952) according to standard procedures. Four potential fungal strains with high titers of xylanase were identified based upon the ITS region, 18S rRNA, 28S rRNA, $\beta$-tubulin and actin gene sequencing at commercial facility provided by Chromous Biotech Pvt. Ltd., and Eurofins Genomics India Pvt. Ltd., Bengaluru, India. Genomic DNA was extracted from the selected fungal isolates according to Al-Samarrai and Schmid (2000) with slight modifications and used for amplification of ITS region, 18S rRNA, nLSU rRNA, $\beta$-tubulin and actin genes using primer pairs ITS1/ITS4 (White et al.1990), n-SSU-0817/nu-SSU-1536 (Borneman and Hartin 2000), LROR/LR7 (Vilgalys and Hester 1990; Rehner and Samuels 1994), BENA1/BENA3 (Davolos et al. 2012) and ACT512F/ACT-783R (Carbone and Kohn 1999), respectively. All nucleotide sequences of the genes were submitted to NCBI GenBank database. Similarity search was carried out for each gene sequence using online BLAST program (http://www.ncbi.nlm.nih.gov/) and analyzed (Table 1) using the ClustalW algorithm available in molecular evolutionary genetic analysis (MEGA X) software with default parameters (Kumar et al. 2018). The phylogenetic tree of the ITS region was generated by employing the maximum likelihood method using Tamura-Nei model (Tamura and Nei 1993) and the evolutionary distance was inferred using the bootstrap method ( $n=1000$ bootstrap replications).

\section{Phylogenetic analysis}

Multigene phylogeny construction through alignment of relevant sequences and trimmed matrices construction of ITS and $n L S U$ as well as ITS, nLSU and $\beta$-tubulin sequences was done through MEGAX. A Bayesian interference (BI) analysis was conducted via MrBayes v3.2.2 (Ronquist et al. 2012) using a GTR + I + Г model (General Time Reversible model) for 3000000 generations with sampling every 100 generations. The settings were as follows: nst $=6$, rates = invgamma, MCMC heated chain set with nchains $=4$ and temp $=0.2$, ngen $=3000000$, samplefreq $=100$. Two independent analysis with four chains each (one cold and three heated) were run until the average standard deviation of the split frequencies dropped below 0.01 . The initial $25 \%$ generations of MCMC sampling were discarded as burn-in. 
Refinement of the phylogenetic tree was used for estimating BI posterior probability (BIPP) values (Zheng et al. 2020). The tree was viewed in FigTree v1.4 (Rambaut 2012).

\section{Enzyme production, partial purification and molecular characterization}

Enzyme production from strains AUMS60 and AUMS64 was carried out as mentioned above with fermentation media supplemented with $3 \%(\mathrm{w} / \mathrm{v})$ corn cob $(\mathrm{pH} 7)$; at $40^{\circ} \mathrm{C}$ on a rotary shaker $(110 \mathrm{rpm})$ for 7 days. Filtered cell free extract was concentrated 10-fold via ultrafiltration membrane with a molecular weight cutoff of 10-kDa (Millipore TFE system, Bedford, MA, USA). Xylanase activity of all samples were determined as mentioned previously and protein quantification was done through Lowry's method using BSA as standard (Lowry et al. 1951).

Electrophoretic analysis of crude and partially purified samples was done through native and SDS PAGE (Ornstein and Davis 1964, Laemlli 1970, Shrivastava et al. 2013) with protein bands developed through silver staining (Blum et al. 1987) documented through Gel documentation system (Bio-Rad Laboratories, Hercules, CA, USA). Zymography was carried out with method of Royer and Nakas (1990) with slight modification. Reagents were procured from Biorad (BioRad Laboratories, Hercules, CA, USA) and Himedia (HiMedia Laboratories Pvt Ltd., Mumbai, India).

\section{Biochemical characterization of partially purified enzymes}

Effect of pH on partially purified enzymes from AUMS60 and AUMS64 was studied at pH 5-8 at $40^{\circ} \mathrm{C}, 50^{\circ} \mathrm{C}$ and $60^{\circ} \mathrm{C}$ (Sodium acetate and Tris chloride buffer, $0.05 \mathrm{~mol} \mathrm{l}^{-1}$ ). Stability at pH 5 and 6 were studied for $120 \mathrm{~h}$ at $40^{\circ} \mathrm{C}$.

Temperature optima was determined by studying catalytic efficiency from $30^{\circ} \mathrm{C}$ to $90^{\circ} \mathrm{C}$. Thermostability was studied at $40^{\circ} \mathrm{C}, 50^{\circ} \mathrm{C}$ and $60^{\circ} \mathrm{C}$. Effect of selective metal ions and chemicals $\left(\mathrm{NaCl}, \mathrm{KCl}, \mathrm{CaCl}_{2}, \mathrm{CuSO}_{4}, \mathrm{MgSO}_{4}, \mathrm{FeSO}_{4}, \mathrm{EDTA}\right.$ and SDS) in dose of 1 and $10 \mathrm{mM}$ was studied by incubation at $50^{\circ} \mathrm{C}$ for $30 \mathrm{~min}$ with respective analyte.

Effect of enzyme dose (20-100 $\mathrm{U} \mathrm{g}^{-1}$ of substrate) was studied on saccharification of purified substrate (1\% (w/v) birchwood xylan prepared in Acetate buffer, $\mathrm{pH}$ 6.0) upto $24 \mathrm{~h}$ with incubation at $40^{\circ} \mathrm{C}$ in rotary shaker at varying speed of 100-140 rpm.

\section{Results}

\section{Screening and selection of GHs producing biocatalysts}

Out of 294 indigenous bacterial and fungal strains isolated from samples at temperature ranging from $20-60^{\circ} \mathrm{C}, 46 \%$ (135) and $12 \%$ (35) were cellulolytic and xylanolytic respectively (Fig. 1a). Among all glycoside hydrolase positive strains $69 \%$ were bacteria and $31 \%$ were fungi with most of them having optimum growth temperature of $40-50^{\circ} \mathrm{C}(\mathrm{Fig}$. $1 \mathrm{~b}$ and $1 \mathrm{c})$, complimenting the site of sample collection.

Hydrolytic zone on substrate supplemented medium ranged from 0.1 to $4 \mathrm{~cm}$ (Fig. 1d). Approximately $40 \%, 11-18 \%$ and $15 \%$ of cellulolytic isolates showed hydrolysis zone ranging from $<0.5 \mathrm{~cm}, 0.6-2.0 \mathrm{~cm}$ and $>2.0 \mathrm{~cm}$, respectively. In case of xylanolytic isolates $45.7 \%, 11-20 \%$ and $23 \%$ species exhibited hydrolysis zone $<1 \mathrm{~cm}, 1.1-2 \mathrm{~cm}$, and $>2 \mathrm{~cm}$, respectively. All isolates with hydrolytic zone greater than $2 \mathrm{~cm}$ were selected for further screening through enrichment media. Four fungal strains identified as most potential glycoside hydrolase producers exhibiting crude $x y l a n a s e(X)$ and cellulase activity $(C)$ were AUMS56 $\left(X=18.9\right.$ and $\left.C=0.28 \mathrm{U} \mathrm{ml}^{-1}\right), \operatorname{AUMS60}\left(X=28.58\right.$ and $\left.\mathrm{C}=0.44 \mathrm{U} \mathrm{ml}^{-1}\right), \mathrm{AUMS}^{-1}$ $\left(X=24.86\right.$ and $\left.C=0.67 \mathrm{U} \mathrm{ml}^{-1}\right)$ and AUKEMS24 $\left(X=15.82 \mathrm{U} \mathrm{ml}^{-1}\right)$. The strains were deposited in National Collection of Industrial Microorganisms (NCIM), National Chemical Laboratory (NCL), Pune, India with the accession numbers, NCIM1422 (AUMS56), NCIM1423 (AUMS60), NCIM1424 (AUMS64) and NCIM1425 (AUKEMS24). 


\section{Morphological characterization and identification of fungal strains by ITS region rDNA sequencing}

All four selected isolates were spore forming filamentous fungi, observed through morphological examination. BLAST analysis for ITS region suggested that strains AUMS56, AUMS60, AUMS64 and AUKEMS24 showed maximum sequence identity to Aspergillus nigerT4 (MG833314.1, 99.68\%), Aspergillus tubingensis CNU081066 (JF411067.1, 99.6\%), Aspergillus nigerZ4 (MH892847.1, 98.97\%) and Aspergillus fumigatus IHEM-18963 (KP131566.1, 98.23\%), respectively. For the amplified $18 \mathrm{~S}$ region, the closest sequence matches for AUMS56, AUMS60, AUMS64 and AUKEMS24 were to A. niger KY (EU184861.1, 98.5\%), A. nigerETYB-13 (GQ903338.1, 99\%), A. niger CBS-554.65 (NG_065763.1, 99.8\%) and A. fumigatus ATCC-13073 (LC485158.1, 99.4\%), respectively. For the amplified nLSU region, the closest sequence match for AUMS56 was to A. terreus (GU362936.1, 96.2\%), AUMS60 and AUMS64 was to A. niger PVF1 (MK273554.1) with 96.1\% and 98.03\% maximum identity, respectively and AUKEMS24 showed 90.8\% identity with A. fumigatus nHF-01 (MN190286.1).

For the amplified $\beta$-tubulin region, the closest sequence matches for AUMS56 and AUKEMS24 were to $A$. terreus (FR775342.1, 88.4\%) and A. fumigatus (AY048754.1, 87.6\%), respectively while AUMS60 and AUMS64 showed maximum identity of $97.3 \%$ and $99.1 \%$ to $A$. pulverulentus (HE984408.1). For the amplified actin region, the closest sequence match for AUMS56 was to $A$. campestris IBT-28561 (XM_024835858.1, 80.6\%), AUMS60 and AUMS64 was to A. niger PL5-2B (MF422182.1) with $90.14 \%$ and $85.9 \%$ identity, respectively and AUKEMS24 was to A. fumigatus (AF076692.1, 98.9\%). The strains were designated based upon the ITS sequence similarity results of BLAST. Their corresponding accession numbers are mentioned in Table 1.

\section{Phylogenetic analysis}

Maximum likelihood phylogenetic tree, generated using ITS region of 40 related sequences through MEGA X and Tamura-Nei model computed the evolutionary distances. The bootstrap consensus tree inferred from 1000 replicates (Felsenstein 1985) was taken to represent the evolutionary history of the taxa analyzed as shown in Supplementary Fig. S1. Strains AUMS56 and AUMS64 formed a sister node to Aspergillus niger while AUMS60 formed sister node to Aspergillus tubingensis. AUKEMS24 formed a separate clade with sister node to Aspergillus fumigatus. Multigene Bayesian analysis involved sequences of the ITS and nLSU rDNA genes from 39 strains. The aligned dataset consisted of 575 and 860 nucleotides from the ITS and nLSU rDNA gene sequences, respectively. Convergence was assumed as an average standard deviation of split frequencies of 0.004545 was achieved following 3000000 generations. From the generated phylogenetic tree (Fig. 2), representative isolates of Aspergillus species clustered together forming 5 phylogroups. Isolates AUMS60 and AUMS64 formed lineage with Aspergillus tubingensis and Aspergillus niger in the first phylogroup with $100 \%$ Bayesian posterior probability support. The well supported sister lineage to this phylogroup was the $A$. niger branch consisting of nine strains. Isolate AUMS56 showed similarity to both $A$. tubingensis and $A$. niger lineages while AUKEMS24 formed discrete lineage with Aspergillus fumigatus, clearly showing deviation from $A$. tubingensis and $A$. niger groups with $100 \%$ posterior probability support. The species $A$. flavus, $A$. keveii and $A$. sydowii all branched as sister lineages forming distinct clades and therefore treated as separate phylogroups. Results obtained from multigene Bayesian analysis involving sequences of the ITS, nLSU rDNA and $\beta$-tubulin genes (data not included) from 23 strains were similar to those obtained from multigene analysis of ITS and nLSU rDNA genes.

\section{Characterization of partially purified xylanase from AUMS60 and AUMS64}

Crude xylanase activity of $A$. tubingensis AUMS60 and $A$. niger AUMS64 was further enhanced to $32.29 \mathrm{U} \mathrm{ml}^{-1}$ (specific activity, $19.5 \mathrm{U} \mathrm{mg}^{-1}$ ) and $30.68 \mathrm{U} \mathrm{ml}^{-1}$ (specific activity, $18.4 \mathrm{U} \mathrm{mg}^{-1}$ ), respectively, upon increasing the concentration of corn cob (though not optimized). Xylanase activity of ultrafiltrate (Amicon $10 \mathrm{kDa}$ cut off filter) obtained from cell free crude extract of AUMS60 and AUMS64 was observed as 316.46 (specific activity, $37.2 \mathrm{U} \mathrm{mg}^{-1}$ ) and $305.14 \mathrm{U} \mathrm{ml}^{-1}$ 
(specific activity, $27.1 \mathrm{U} \mathrm{mg}^{-1}$ ), respectively. Zymography suggested single xylanase from AUMS60 and two isoforms from AUMS64. Xylanase have been designated as Xyn60, Xyn64A and Xyn64B having molecular mass of approximately $36,33.4$ and $19.8 \mathrm{kDa}$, respectively (Fig. 3).

Temperature optima for AUMS60 xylanase was determined as $60^{\circ} \mathrm{C}$, while xylanases from AUMS64 showed almost same activity at $60^{\circ} \mathrm{C}$ and $70^{\circ} \mathrm{C}$ (Fig. 4a). Although all xylanases in the study significantly lost their activity at $80^{\circ} \mathrm{C}$ and above. pH optima for all the enzymes at varied temperature range was determined as 6.0 (Fig. 4b).

Stability of partially purified xylanases determined at pH 5 and 6 for 120 hours showed $90 \%$ retention in activity till $96 \mathrm{~h}$ at $\mathrm{pH} 6$ while $70 \%$ activity at $\mathrm{pH} 5$ for AUMS60. Xylanases from AUMS64 were also comparatively stable (>70\% residual activity) at both $\mathrm{pH} 5$ and 6 (Fig. 4c).

All xylanases, Xyn60, Xyn64A and Xyn64B worked at pH 6.0, were stable at $40^{\circ} \mathrm{C}$ for more than $120 \mathrm{~h}$, with considerable loss at $50^{\circ} \mathrm{C}$ and almost complete loss in activity at $60^{\circ} \mathrm{C}$ (Fig. $4 \mathrm{C}$ and $4 \mathrm{~d}$ ). Although temperature optima for all xylanases was $60^{\circ} \mathrm{C}$, they were highly unstable at that temperature. A comparative analysis of xylanases exhibiting differing $\mathrm{pH}$ and thermal stability over a wide range reported in previous studies from Aspergillus species is shown in Table 2.

Study of metal ions and chemicals on xylanases suggested $\mathrm{Na}^{+1}$ and $\mathrm{K}^{+1}$ as significant enhancer for Xyn60, Xyn64A and Xyn64B. $\mathrm{Cu}^{+2}$ acted as activator at low dose and inhibitor at high dose for overall Xyn64A and Xyn64B; while inhibitor at all dose for Xyn60. $\mathrm{MgSO}_{4}$ at lower dose acted as moderate enhancer for all Xyn60, Xyn64A and Xyn64B and inhibitor for Xyn64A and Xyn64B at high dose. $\mathrm{CaCl}_{2}$ and $\mathrm{FeSO}_{4}$ had varied effects at different dose on Xyn60, Xyn64A and Xyn64B. EDTA and SDS showed inhibitory effect on activity for Xyn60, Xyn64A and Xyn64B at all dose conditions (complete data detailed as Table 3).

Study of saccharification efficiency of all xylanases observed in our investigation suggested maximum saccharification with enzyme dose of $100 \mathrm{U} \mathrm{g}^{-1}$ of substrate at $140 \mathrm{rpm}$, showing $51.1 \%$ at $13 \mathrm{~h}$ and $52.2 \%$ at $24 \mathrm{~h}$ incubation for AUMS60 and AUMS64, respectively (Fig. 5).

\section{Discussion}

Extensive isolation and screening procedure based on various identification techniques suggested AUMS56 (Aspergillus niger), AUMS60 (Aspergillus tubingensis), AUMS64 (Aspergillus niger) and AUKEMS24 (Aspergillus fumigatus) as most potential extracellular xylanase producers from all indigenous isolates taken for study. Complete identification of these organisms to species level was done through multigene analysis. AUMS60 and AUMS64 were found to be most ideal extracellular xylanase producers among 294 strains studied and formed a discrete clade with Aspergillus tubingensis and Aspergillus niger with 100\% Bayesian Inference posterior probability. Multigene analysis could not be carried out by involving the sequences of 18S rDNA and actin genes because of lack of availability of resources in the database. AUMS60, AUMS64 and AUMS56 were both cellulolytic and xylanolytic, whereas AUKEMS24 was only xylanolytic.

A cocktail of biocatalysts producing cellulases and xylanases simultaneously alludes to be an ideal approach towards the saccharification of complex lignocelluloses to obtain simpler sugars in biorefineries. AUMS60 and AUMS64 could produce xylanase with crude extract activity of 19.69 and $17.32 \mathrm{U} \mathrm{ml}^{-1}$, respectively over 3 days of incubation using corncob as substrate. Though a significant xylanase production was obtained within 3 days, it persistently increased reaching maximum xylanase activity of $28.58 \mathrm{U} \mathrm{ml}^{-1}\left(1429 \mathrm{U} \mathrm{g}^{-1}\right)$ and $24.86 \mathrm{U} \mathrm{ml}^{-1}\left(1243 \mathrm{U} \mathrm{g}^{-1}\right)$ for AUMS60 and AUMS64, respectively over 10 days. The activity was further enhanced to $32.29 \mathrm{U} \mathrm{ml}^{-1}$ (AUMS60) and $30.68 \mathrm{U} \mathrm{ml}^{-1}$ 
(AUMS64) in only 7 days upon changing parameters such as $\mathrm{pH}$ and concentration of corn cob (though not optimized). All these xylanases had pH optima as 6.0 and temperature optima as $60^{\circ} \mathrm{C}$ and were stable at both pH 5.0 and 6.0 for more than $120 \mathrm{~h}$, but completely lost temperature tolerance even at $50^{\circ} \mathrm{C}$ after $48 \mathrm{~h}$ of incubation.

Corncob has significant amount of xylan content as compared to numerous other industrially significant agricultural residues (wheat bran, rice husk etc), thereby making it a potential substrate for xylanase production (Knob et al. 2014). Moreover, the abundance and easy availability of corncob in India facilitated for the screening of xylanolytic microbes. Bandikari et al. (2014) reported xylanase activity of $810.7 \mathrm{U} \mathrm{g}^{-1}$ produced from Trichoderma koeningi $\left(30^{\circ} \mathrm{C} / 7 \mathrm{days}\right)$ from corn cob. Streptomyces sp. MSC702 produced xylanase with activity of $6.23 \mathrm{U} \mathrm{ml}^{-1}$ at $50^{\circ} \mathrm{C}$ incubation for $48 \mathrm{~h}$ (Singh et al. 2012). Xylanase production using corn cob alone or in combination with other substrates has also been reported for A. niger (10.5 $\mathrm{U} \mathrm{ml}^{-1}$ ) and A. flavus (11.92 $\mathrm{U} \mathrm{ml}^{-1}$ ) (de Alencar Guimaraes et al. 2013), Aspergillus flavus (65 $\mathrm{U} \mathrm{ml}^{-1}$ ) (Chen et al. 2019) and most recently Penicillium purpurogenum (84.61 $\mathrm{U} \mathrm{ml}^{-1}$, using delignified corn cob) (Sunkar et al. 2020).

Two isozymes of xylanase were secreted by AUMS64 (Xyn64A and Xyn64B) and one xylanase (Xyn60) by AUMS60 that were comparable in size to various other xylanases as in A. flavus (20.2 kDa) (Chen et al. 2019), A. terreus S9 (33 kDa) (Sharma et al. 2018), A. fumigatus (20 kDa) (Lin et al. 2017) and A. japonicus PJ01 (20-34 kDa) (Li et al. 2015). Several xylanases of this molecular mass have been successfully cloned and expressed in both bacteria and yeasts including E. coli, Saccharomyces cerevisiae and Pichia stipitis (Alokika and Singh 2019). Hence, our enzymes hold great potential for production of genetically modified organisms with enhanced saccharification efficiencies for complex lignocelluloses. Different fungal strains such as Penicillium ramulosum N1, Aspergillus sp., Clostridium and Streptomyces sp., A. fumigatus SK1 and N2 (Lin et al. 2017) have been reported for producing multiple forms of xylanase. These isozymic forms may have different biochemical properties and specific activity which may impart stability over broad range of $\mathrm{pH}$ and temperature. Microbial isolates producing isozymes with different yield and xylan hydrolysis efficiency are considered more suitable for industrial use (Singh et al. 2020).

The optimum $\mathrm{pH}$ of enzymes obtained in this study is similar to that observed for xylanases from $A$. clavatus (Pasin et al. 2020), A. niger (Suleman et al. 2016) and A. fumigatus (Carvalho et al. 2015; Lin et al. 2017). The optimal temperature is in agreement with xylanases produced by A. niger Gyx086 (Wang et al. 2019), Aspergillus cf. tubingensis LAMAl 31 (Dos Santos et al. 2016), A. fumigatus (Carvalho et al. 2015), A. niger and A. flavus (de Alencar Guimaraes et al. 2013) that presented optimal temperatures ranging from $50-60^{\circ} \mathrm{C}$. The enzymes obtained in this study showed $\mathrm{pH}$ stability at both pH 5 and 6 over long periods of time (more than 72 hours), which is highly significant for their use in industrial processes operating for longer durations. Moreover, the enzymes work perfectly around $\mathrm{pH} 6$, which is the optimal pH for many industrial processes. Enzymes from AUMS60 and AUMS64 showed high temperature stability at $40^{\circ} \mathrm{C}$ (greater than $120 \mathrm{~h}$ ) and could also retain about $80 \%$ activity for $4 \mathrm{~h}$ and $90 \%$ activity for $24 \mathrm{~h}$ at $50^{\circ} \mathrm{C}$,

respectively. The results were more encouraging as compared to various other studies as mentioned in Table 2. Even if the $\mathrm{pH}$ stability is slightly less, the storage temperature for our enzymes $\left(40^{\circ} \mathrm{C}\right)$ is higher than most of the studies $(0-$ $25^{\circ} \mathrm{C}$ ) which indicate their application at even high temperatures.

As reported through previous studies, cations have enhancing or inhibitory action on enzyme catalysis, thus was observed for xylanases in our study with sodium and potassium resulting in $80-100 \%$ increase in residual enzyme activity and cupric ion showing potential inhibition. This study is ideally performed with purified enzymes and have been reported for xylanase from $A$. terreus $\mathrm{S} 9$, which was strongly inhibited in the presence of $(10 \mathrm{mM}) \mathrm{Hg}^{2+} \mathrm{and} \mathrm{Cu}^{2+}$ while $\mathrm{Mg}^{2+}, \mathrm{Fe}^{2+}, \mathrm{Co}^{2+}$ and EDTA caused slight to moderate inhibition, but $\mathrm{Ca}^{2+}, \mathrm{Mn}^{2+}$ and $\mathrm{K}^{+}$promoted the activity (Sharma et al. 2018). Xylanases from A. clavatus NRRL1 were found to show halotolerance, exhibiting a relative activity of $110 \%$ in the presence of $10 \mathrm{mM} \mathrm{NaCl}$ and maintaining more than $90 \%$ relative activity over the $\mathrm{NaCl}$ range of 
0.04-0.2 M (Pasin et al. 2020). Activity of partially purified xylanase from Aspergillus oryzae LC1 increased in presence of $\mathrm{Fe}^{+2}, \mathrm{Mg}^{+2}, \mathrm{Mn}^{+}, \mathrm{Co}^{+}$and $\mathrm{Ag}^{2+}$ but inhibited by $\mathrm{CuSO}_{4}, \mathrm{HgCl}_{2}, \mathrm{ZnCl}_{2}$ and EDTA (Bhardwaj et al. 2019).

The presence of xylan intertwined with cellulosic component in the lignocellulosic biomass creates resistance for efficient conversion of biomass into fermentable sugars. Therefore, we evaluated the performance of the xylanase enzymes obtained from AUMS60 and AUMS64 for depolymerization of birchwood xylan. In our study, the saccharification efficiency of AUMS60 and AUMS64 xylanases was found to be $51.1 \%$ (4.84 mg ml-1 reducing sugars) and $52.2 \%$ (4.95 mg ml${ }^{-1}$ reducing sugars) in 13 and 24 hours, respectively when used at an enzyme dosage of 100 Units $\mathrm{g}^{-1}$ substrate. A xylanase from $S$. variabilis MAB3 was reported to achieve maximum saccharification efficiency of $51.1 \%$ from birchwood xylan in 72 hours by Sanjivkumar et al. (2018). Pleurotus ostreatus xylanase (rXyn162) resulted in the release of $88.4 \mathrm{mg} \mathrm{l}^{-1}$ reducing sugars from oat spelt xylan (Zhuo et al. 2018). In another study by Tu et al. (2019), the levels of xylo-oligosaccharides released via depolymerization of wheat-arabinoxylan, reached $451.4 \mathrm{mg} \mathrm{I}^{-1}$ within 12 hours of incubation using xylanase from Termoascus crustaceus JCM12803. In view of the previous findings, the enzymes used in our study accomplish better saccharification of birchwood xylan in much less time even while using low dosages of enzyme. Moreover, we have used enzymes that are partially purified (one-step purification). Most of the previous studies have utilized enzymes that have been purified to homogeneity, which again increases the cost of the enzymatic saccharification process. In order to develop a cost effective and efficient process for enzymatic saccharification of biomass, maximal fermentable sugars need to be released while maintaining minimum expenditures on the cost of enzymes as well as on the hydrolysis time.

There is a surge of interest in the investigation for xylanolytic microorganism for their use in various industries. Two potent fungal strains of Aspergillus sp. in this study produced significant levels of glycosyl hydrolases on raw corn cob as substrate and the xylanases produced were of high catalytic strength. Profiling of physico-chemical characteristics of these enzymes namely Xyn60, Xyn64A and Xyn64B suggested their industrial significance. Effect of metal ions, $\mathrm{pH}$ and temperature optima and stability, catalytic strength of the enzymes provides great scope for further studying enzymatic cocktail for enhanced biomass valorization that can be highly beneficial since utilizing these microbes not only helps in waste reduction and management but also leads to development of cost-effective processes for production of enzymes and successive value-added components. To the best of our knowledge we report that the enzymes in our study hydrolyzed birchwood xylan with higher saccharification efficiency than most of the previous findings. Based on this work, process optimization (e.g. enzymatic hydrolysis of substrate, dosages of AUMS60 and AUMS64 xylanases) may be ensued to improve the transformation rates of hemicellulose from varied lignocelluloses. Our findings suggest that these enzymes are better candidates for production of reducing sugar from complex polysaccharides, enabling their use in the various industries.

\section{Declarations}

\section{Acknowledgements}

The authors acknowledge the Science and Engineering Research Board (SERB), Government of India, for supporting the present work at Amity University Uttar Pradesh, Noida, India.

\section{Availability of data and material}

All data generated or analyzed during this study are included in this article and its supplementary information files.

\section{Authors' contributions}


MR conducted experiments, analyzed data and wrote the manuscript. SS contributed in supervision, funding acquisition, review and editing. PS advised for final correspondence of the manuscript. All authors read and approved the manuscript.

\section{Funding information}

The work here was funded by DST- SERB, New Delhi, India (project-grant number YSS/2015/002072) received by SS.

\section{Compliance with ethical standards}

\section{Conflict of interest}

The authors declare that there are no conflicts of interest.

\section{Ethical statement}

This article does not contain any studies with human participants or animals performed by any of the authors.

\section{References}

1. Al-Samarrai TH, Schmid J (2000) A simple method for extraction of fungal genomic DNA. Lett Appl Microbiol 30(1): 53-56. doi: 10.1046/j.1472-765x.2000.00664.x

2. Alokika, Singh B (2019) Production, characteristics, and biotechnological applications of microbial xylanases. Appl Microbiol Biotechnol 103(21-22): 8763-8784. doi: 10.1007/s00253-019-10108-6

3. Amaro-Reyes A, Gracida J, Huizache-Peña N, Elizondo-García N, Salazar-Martínez J, García-Almendárez BE, Regalado C (2016) On-site hydrolytic enzymes production from fungal co-cultivation of Bermuda grass and corn cob. Bioresour Technol 212: 334-337. doi: 10.1016/j.biortech.2016.04.070

4. Bailey MJ, Biely P, Poutanen K (1992) Inter laboratory testing of methods for assay of xylanase activity. J Biotechnol 23(3): 257-270. doi:10.1016/0168-1656(92)90074-J

5. Bandikari R, Poondla V, Obulam VS (2014) Enhanced production of xylanase by solid state fermentation using Trichoderma koeningi isolate: effect of pretreated agro-residues. 3 Biotech 4(6): 655-664. doi: 10.1007/s13205014-0239-4

6. Bartholomew JW, Mittwer T (1952) The Gram stain. Bacteriol Rev 16(1): 1-29.

7. Bhalla A, Bansal N, Kumar S, Bischoff KM, Sani RK (2013) Improved lignocellulose conversion to biofuels with thermophilic bacteria and thermostable enzymes. Bioresour Technol 128: 751-759. doi:

10.1016/j.biortech.2012.10.145

8. Bhardwaj N, Kumar B, Agarwal K, Chaturvedi V, Verma P (2019) Purification and characterization of a thermoacid/alkali stable xylanases from Aspergillus oryzae LC1 and its application in Xylo-oligosaccharides production from lignocellulosic agricultural wastes. Int J Biol Macromol 122: 1191-1202. doi: 10.1016/j.ijbiomac.2018.09.070

9. Bibra M, Kunreddy VR, Sani RK (2018) Thermostable Xylanase Production by Geobacillus sp. Strain DUSELR13, and Its Application in Ethanol Production with Lignocellulosic Biomass. Microorganisms 6(3): 93. doi: 10.3390/microorganisms6030093

10. Blum H, Beier H, Gross B (1987) Improved silver staining of plant proteins, RNA and DNA in polyacrylamide gels. Electrophoresis 8(2): 93-99. https://doi.org/10.1002/elps.1150080203

11. Borneman J, Hartin JR (2000) PCR Primers That Amplify Fungal rRNA Genes from Environmental Samples. Appl Environ Microbiol 66(20): 4356-4360. doi: 10.1128/aem.66.10.4356-4360.2000 
12. Carbone I, Kohn LM (1999) A method for designing primer sets for speciation studies in filamentous ascomycetes. Mycologia 91(3): 553-556. doi: 10.1080/00275514.1999.12061051

13. Carvalho AF, Neto PO, Zaghetto de Almeida P, Bueno da Silva J, Escaramboni B, Pastore GM (2015) Screening of Xylanolytic Aspergillus fumigatus for Prebiotic Xylooligosaccharide Production Using Bagasse. Food Technol Biotechnol 53(4): 428-435. doi: 10.17113/ftb.53.04.15.4160

14. Chadha BS, Kaur B, Basotra N, Tsang A, Pandey A (2019) Thermostable xylanases from thermophilic fungi and bacteria: current perspective. Bioresour Technol 277: 195-203. doi: 10.1016/j.biortech.2019.01.044

15. Chen Z, Zaky AA, Liu Y, Chen Y, Liu L, Li S, Jia Y (2019) Purification and characterization of a new xylanase with excellent stability from Aspergillus flavus and its application in hydrolyzing pretreated corncobs. Protein Expr Purif 154: 91-97. doi: 10.1016/j.pep.2018.10.006

16. Davolos D, Pietrangeli B, Persiani AM, Maggi O (2012) Penicillium simile sp. nov. revealed by morphological and phylogenetic analysis. Int J Syst Evol Microbiol 62(2): 451-458. doi: 10.1099/ijs.0.031682-0

17. de Alencar Guimaraes NC, Sorgatto M, Peixoto-Nogueira S, Betini JH, Zanoelo FF, Marques MR, de Moraes Polizeli M, Giannesi GC (2013) Bioprocess and biotecnology: effect of xylanase from Aspergillus niger and Aspergillus flavus on pulp biobleaching and enzyme production using agroindustrial residues as substract. SpringerPlus 2 , 380. doi: 10.1186/2193-1801-2-380

18. Dias LM, Dos Santos BV, Albuquerque CJB, Baeta BEL, Pasquini D, Baffi MA (2018) Biomass sorghum as a novel substrate in solid-state fermentation for the production of hemicellulases and cellulases by Aspergillus niger and A. fumigatus. J Appl Microbiol 124(3): 708-718. doi: 10.1111/jam.13672

19. Dos Santos JA, Vieira J, Videira A, Meirelles LA, Rodrigues A, Taniwaki MH, Sette LD (2016) Marine-derived fungus Aspergillus cf. tubingensis LAMAI 31: a new genetic resource for xylanase production. AMB Express 6: 25. doi: 10.1186/s13568-016-0194-z

20. Felsenstein J (1985) Confidence limits on phylogenies: An approach using the bootstrap. Evolution 39(4):783-791. doi: 10.1111/j.1558-5646.1985.tb00420.x

21. Ghose TK (1987) Measurement of cellulase activities. Pure Appl Chem 59(2): 257-268. doi.org/10.1351/pac198759020257

22. Guo G, Liu Z, Xu J, Liu J, Dai X, Xie D, Peng K, Feng X, Duan S, Zheng K, Cheng L, Fu Y (2012) Purification and characterization of a xylanase from Bacillus subtilis isolated from the degumming line. J Basic Microbiol 52(4): 419-428. doi: 10.1002/jobm.201100262

23. Kumar S, Stecher G, Li M, Knyaz C, Tamura K (2018) MEGA X: Molecular Evolutionary Genetics Analysis across computing platforms. Mol Biol Evol 35(6): 1547-1549. doi: 10.1093/molbev/msy096

24. Knob A, Fortkamp D, Prolo T, Izidoro SC, Almeida JM (2014) Agro-residues as alternative for xylanase production by filamentous fungi. BioResources 9: 5738-5773.

25. Laemlli UK (1970) Cleavage of structural proteins during the assembly of the head of bacteriophage T4. Nature 227(5259): 680-685. doi: 10.1038/227680a0

26. Leck A (1999) Preparation of lactophenol cotton blue slide mounts. Community Eye Health 12: 24.

27. Li PJ, Xia JL, Shan Y, Nie ZY (2015) Comparative study of multi-enzyme production from typical agro-industrial residues and ultrasound-assisted extraction of crude enzyme in fermentation with Aspergillus japonicus PJ01. Bioprocess Biosyst Eng 38: 2013-2022. doi: 10.1007/s00449-015-1442-3

28. Lin C, Shen Z, Qin W (2017) Characterization of Xylanase and Cellulase Produced by a Newly Isolated Aspergillus fumigatus N2 and Its Efficient Saccharification of Barley Straw. Appl Biochem Biotechnol 182: 559-569. doi:

$10.1007 /$ s12010-016-2344-9

Page $11 / 23$ 
29. Lowry OH, Rosebrough NJ, Farr AL, Randall RJ (1951) Protein measurement with the folin phenol reagent. J Biol Chem 193(1): 265-275.

30. Miller GL (1959) Use of 3, 5- dinitrosalicylic acid reagent for determination of reducing sugar. Anal Chem 31(3): 426- 428. doi: 10.1021/ac60147a030

31. Ornstein L, Davis BJ (1964) Disc electrophoresis. I. Background and theory. Ann. N.Y. Acad. Sci. 121: $321-349$.

32. Pasin TM, Salgado JCS, Scarcella ASdA, Oliveira TBd, Lucas RCd, Cereia M, Rosa JC, Ward RJ, Buckeridge MS, Polizeli MdLTdM (2020) A Halotolerant Endo-1,4- $\beta$-Xylanase from Aspergillus clavatus with Potential Application for Agroindustrial Residues Saccharification. Appl Biochem Biotechnol 191: 1111-1126. doi: 10.1007/s12010-02003232-x

33. Polizeli ML, Rizzatti AC, Monti R, Terenzi HF, Jorge JA, Amorim DS (2005) Xylanases from fungi: properties and industrial applications. Appl Microbiol Biotechnol 67(5): 577-591. doi: 10.1007/s00253-005-1904-7

34. Rambaut A (2012) FigTree v1.4.2. http:// tree. bio. ed. ac. uk / software/figtree/

35. Rastogi M, Shrivastava S (2017) Recent advances in second generation bioethanol production: an insight to pretreatment, saccharification and fermentation processes. Renew Sustain Energy Rev 80: 330-340. doi:

10.1016/j.rser.2017.05.225

36. Rastogi M, Shrivastava S (2020) Glycosyl Hydrolases and Biofuel. In: Shrivastava S (ed) Industrial Applications of Glycoside Hydrolases. Springer, Singapore, pp. 167-190.

37. Rehner SA, Samuels GJ (1994) Taxonomy and phylogeny of Gliocladium analysed from nuclear large subunit ribosomal DNA sequences. Mycol Res 98(6): 625-634. doi: 10.1016/S0953-7562(09)80409-7

38. Ronquist F, Teslenko M, van der Mark P, Ayres DL, Darling A, Hohna S, Larget B, Liu L, Suchard MA, Huelsenbeck JP (2012) MrBayes 3.2: Efficient Bayesian phylogenetic inference and model choice across a large model space. Syst Biol 61(3): 539-542. doi: 10.1093/sysbio/sys029

39. Royer JC, Nakas JP (1990) Simple, sensitive zymogram technique for detection of xylanase activity in polyacrylamide gels. Appl Environ Microbiol 56(6): 1516-1517. doi: 10.1128/AEM.56.6.1516-1517.1990

40. Sanjivkumar M, Silambarasan T, Balagurunathan R, Immanuel G (2018) Biosynthesis, molecular modeling and statistical optimization of xylanase from a mangrove associated actinobacterium Streptomyces variabilis (MAB3) using Box-Behnken design with its bioconversion efficacy. Int J Biol Macromol 118: 195-208. doi: 10.1016/j.jjbiomac.2018.06.063

41. Sharma S, Sharma V, Nargotra P, Bajaj BK (2018) Process desired functional attributes of an endoxylanase of GH10 family from a new strain of Aspergillus terreus S9. Int J Biol Macromol 115: 663-671. doi: 10.1016/j.ijbiomac.2018.04.096

42. Shrivastava S, Shukla P, Mukhopadhyay K (2011) Purification and preliminary characterization of a xylanase from Thermomyces lanuginosus strain SS-8. 3 Biotech 1(4): 255-259. doi: 10.1007/s13205-011-0032-6

43. Shrivastava S, Shukla P, Deepalakshmi PD, Mukhopadhyay K (2013) Characterization, cloning and functional expression of novel xylanase from Thermomyces lanuginosus SS-8 isolated from self-heating plant wreckage material. World J Microbiol Biotechnol 29(12): 2407-2415. doi: 10.1007/s11274-013-1409-y

44. Shrivastava S (2020) Introduction to Glycoside Hydrolases: Classification, Identification and Occurrence In: Shrivastava S (ed) Industrial Applications of Glycoside Hydrolases. Springer, Singapore, pp. 3-84.

45. Singh A, Sharma D, Varghese LM, Mahajan R (2020) Fast flow rate processes for purification of alkaline xylanase isoforms from Bacillus pumilus AJK and their biochemical characterization for industrial application purposes. Biotechnol Prog 36(1): e2898. doi: 10.1002/btpr.2898 
46. Singh R, Kapoor V, Kumar V (2012) Utilization of Agro-industrial Wastes for the Simultaneous Production of Amylase and Xylanase by Thermophilic Actinomycetes. Braz J Microbiol 43(4): 1545-1552. doi: 10.1590/S1517838220120004000039

47. Suleman M, Bukhari IH, Aujla MI, Faiz AH (2016) Production and characterization of xylanase from Aspergillus niger using wheat bran, corn cobs and sugar cane bagasse as carbon sources with different concentrations. $J$ Bioresour Manag 3(1): 1-10.

48. Sunkar B, Kannoju B, Bhukya B (2020) Optimized Production of Xylanase by Penicillium purpurogenum and Ultrasound Impact on Enzyme Kinetics for the Production of Monomeric Sugars from Pretreated Corn Cobs. Front Microbiol 11: 772. doi: 10.3389/fmicb.2020.00772

49. Taddia A, Brandaleze GN, Boggione MJ, Bortolato SA, Tubio, G. (2020) An integrated approach to the sustainable production of xylanolytic enzymes from Aspergillus niger using agro-industrial by-products. Prep Biochem Biotechnol 50(10): 979-991. doi: 10.1080/10826068.2020.1777425

50. Tamura K, Nei M (1993) Estimation of the number of nucleotide substitutions in the control region of mitochondrial DNA in humans and chimpanzees. Mol Biol Evol 10(3): 512-526. doi:

10.1093/oxfordjournals.molbev.a040023

51. Teather RM, Wood PJ (1982) Use of congo red-polysaccharide interactions in enumeration and characterization of cellulolytic bacteria from the bovine rumen. Appl Env Microbiol 43(4): 777-780. doi: 10.1128/AEM.43.4.777780.1982

52. Tu T, Li X, Meng K, Bai Y, Wang Y, Wang Z, Yao B, Luo H (2019) A GH51 a-L-arabinofuranosidase from Talaromyces leycettanus strain JCM12802 that selectively drives synergistic lignocellulose hydrolysis. Microb Cell Fact 18: 138. doi: 10.1186/s12934-019-1192-z

53. Uday USP, Majumdar R, Tiwari ON, Mishra U, Mondal A, Bandyopadhyay TK, Bhunia B (2017) Isolation, screening and characterization of a novel extracellular xylanase from Aspergillus niger (KP874102.1) and its application in orange peel hydrolysis. Int J Biol Macromol 105: 401-409. doi: 10.1016/j.ijbiomac.2017.07.066

54. Varghese LM, Agrawal S, Sharma D, Mandhan RP, Mahajan R (2017) Cost-effective screening and isolation of xylano-cellulolytic positive microbes from termite gut and termitarium. 3 Biotech 7: 108. doi: 10.1007/s13205-0170733-6

55. Vilgalys R, Hester M (1990) Rapid genetic identification and mapping of enzymatically amplified ribosomal DNA from several Cryptococcus species. J Bacteriol 172: 4238-4246. doi: 10.1128/jb.172.8.4238-4246.1990

56. Wang J, Chen X, Chio C, Yang C, Su E, Jin Y, Cao F, Qin W (2019) Delignification overmatches hemicellulose removal for improving hydrolysis of wheat straw using the enzyme cocktail from Aspergillus niger. Bioresour Technol 274: 459-467. doi: 10.1016/j.biortech.2018.12.029

57. White TJ, Bruns T, Lee S, Taylor J (1990) Amplification and direct sequencing of fungal ribosomal RNA genes for phylogenetics. In Innis MA, Gelfand DH, Sninsky JJ, White TJ (ed) PCR Protocols: a guide to methods and applications. Academic Press, San Diego, pp. 315-322.

58. Zheng H, Yu Z, Xu J, Castañeda-Ruiz RF, Qiao M (2020) Ramichloridium endophyticum sp. nov., a novel species of endophytic fungus from Potamogeton pectinatus. Int J Syst Evol Microbiol 70(5): 3433-3439. doi:

10.1099/ijsem.0.004190

59. Zhuo R, Yu H, Qin X, Ni H, Jiang Z, Ma F, Zhang X (2018) Heterologous expression and characterization of a xylanase and xylosidase from white rot fungi and their application in synergistic hydrolysis of lignocellulose. Chemosphere 212: 24-33. doi: 10.1016/j.chemosphere.2018.08.062

\section{Tables}

Page $13 / 23$ 
Table 1

Species, strains and the corresponding GenBank accession numbers of sequences used for phylogenetic analysis

\begin{tabular}{|c|c|c|c|c|c|c|c|}
\hline \multirow{2}{*}{$\begin{array}{l}\text { Sl. } \\
\text { No. }\end{array}$} & \multirow[t]{2}{*}{ Species } & \multirow[t]{2}{*}{ Strain } & \multicolumn{5}{|c|}{ GenBank accession number } \\
\hline & & & ITS & LSU & $\beta$-tubulin & actin & 18S rRNA \\
\hline 1 & $\begin{array}{l}\text { Aspergillus } \\
\text { niger }\end{array}$ & AUMS56 & MT802125.1 & MT777258.1 & MW116992 & MW116998 & MH532514.1 \\
\hline 2 & $\begin{array}{l}\text { Aspergillus } \\
\text { tubingensis }\end{array}$ & AUMS60 & MN153521.1 & MT776892.1 & MW116993 & MW116997 & MH532516.1 \\
\hline 3 & $\begin{array}{l}\text { Aspergillus } \\
\text { niger }\end{array}$ & AUMS64 & MN153517.1 & MT777242.1 & MW116994 & MW116996 & MH532513.1 \\
\hline 4 & $\begin{array}{l}\text { Aspergillus } \\
\text { fumigatus }\end{array}$ & AUKEMS24 & MN153510.1 & MT777617.1 & MW116991 & MW116999 & MH532512.1 \\
\hline 5 & $\begin{array}{l}\text { Aspergillus } \\
\text { fumigatus }\end{array}$ & CBS 542.75 & MH860951.1 & MH872719.1 & AY685153.1 & - & - \\
\hline 6 & $\begin{array}{l}\text { Aspergillus } \\
\text { fumigatus }\end{array}$ & CBS 123.59 & MH857830.1 & MH869367.1 & AY685158.1 & - & - \\
\hline 7 & $\begin{array}{l}\text { Aspergillus } \\
\text { neoglaber }\end{array}$ & CBS 111.55 & MH857397.1 & MH868937.1 & AB201359.1 & - & - \\
\hline 8 & $\begin{array}{l}\text { Aspergillus } \\
\text { fumigatus }\end{array}$ & CBS 386.75 & MH860929.1 & MH872681.1 & AY685168.1 & - & - \\
\hline 9 & $\begin{array}{l}\text { Aspergillus } \\
\text { fumigatus }\end{array}$ & CBS 158.71 & MH860046.1 & MH871825.1 & AY685159.1 & - & - \\
\hline 10 & $\begin{array}{l}\text { Aspergillus } \\
\text { tubingensis }\end{array}$ & CBS 116.36 & MH855725.1 & MH867237.1 & FJ629308.1 & - & - \\
\hline 11 & $\begin{array}{l}\text { Aspergillus } \\
\text { tubingensis }\end{array}$ & CBS 103.12 & MH854604.1 & MH866130.1 & FJ629307.1 & - & - \\
\hline 12 & $\begin{array}{l}\text { Aspergillus } \\
\text { tubingensis }\end{array}$ & CBS 425.65 & MH858651.1 & MH870293.1 & FJ629315.1 & - & - \\
\hline 13 & $\begin{array}{l}\text { Aspergillus } \\
\text { tubingensis }\end{array}$ & CBS 107.55 & FJ629367.1 & MH868934.1 & FJ629318.1 & - & - \\
\hline 14 & $\begin{array}{l}\text { Aspergillus } \\
\text { tubingensis }\end{array}$ & CBS 130.52 & FJ629359.1 & MH868481.1 & FJ629310.1 & - & - \\
\hline 15 & $\begin{array}{l}\text { Aspergillus } \\
\text { niger }\end{array}$ & CBS 554.65 & FJ629337.1 & MH870353.1 & FJ629288.1 & - & MH748223.1 \\
\hline 16 & $\begin{array}{l}\text { Aspergillus } \\
\text { niger }\end{array}$ & LBM 134 & MK457457.1 & MK463630.1 & MK465342.1 & - & - \\
\hline 17 & $\begin{array}{l}\text { Aspergillus } \\
\text { niger }\end{array}$ & $\begin{array}{l}\text { ATCC } \\
16888\end{array}$ & AY373852.1 & KU729129.1 & KU897009.1 & - & - \\
\hline 18 & $\begin{array}{l}\text { Aspergillus } \\
\text { niger }\end{array}$ & $\begin{array}{l}\text { ATCC } \\
16404\end{array}$ & AY939787.1 & AF454170.1 & FJ608395.1 & - & - \\
\hline 19 & $\begin{array}{l}\text { Aspergillus } \\
\text { spelaeus }\end{array}$ & IG136 & MG976683.1 & MG977424.1 & MH001463.1 & - & - \\
\hline 20 & $\begin{array}{l}\text { Aspergillus } \\
\text { keveii }\end{array}$ & CBS 209.92 & MH862354.1 & MH874019.1 & EU076376.1 & EU076348.1 & - \\
\hline
\end{tabular}




\begin{tabular}{|c|c|c|c|c|c|c|c|}
\hline 21 & $\begin{array}{l}\text { Aspergillus } \\
\text { fumigatus }\end{array}$ & SZJ01 & MK240371.1 & MK240374.1 & - & - & MK240373.1 \\
\hline 22 & $\begin{array}{l}\text { Aspergillus } \\
\text { sydowii }\end{array}$ & ASAU-1 & KJ524907.1 & KJ524908.1 & KJ524906.1 & - & - \\
\hline 23 & $\begin{array}{l}\text { Aspergillus } \\
\text { terreus }\end{array}$ & RCBC_1002 & GU362937.1 & GU362936.1 & - & - & - \\
\hline 24 & $\begin{array}{l}\text { Aspergillus } \\
\text { fumigatus }\end{array}$ & $\begin{array}{l}\text { ATCC } \\
16907\end{array}$ & AY214446.1 & AY216670.1 & - & - & - \\
\hline 25 & $\begin{array}{l}\text { Aspergillus } \\
\text { fumigatus }\end{array}$ & $\begin{array}{l}\text { CBS } \\
126847\end{array}$ & MH864332.1 & MH875778.1 & - & - & - \\
\hline 26 & $\begin{array}{l}\text { Aspergillus } \\
\text { fumigatus }\end{array}$ & $\begin{array}{l}\text { CBS } \\
130584\end{array}$ & MH865795.1 & MH877225.1 & - & - & - \\
\hline 27 & $\begin{array}{l}\text { Aspergillus } \\
\text { fumigatus }\end{array}$ & $\begin{array}{l}\text { CBS } \\
129448\end{array}$ & MH865339.1 & MH876789.1 & - & - & - \\
\hline 28 & $\begin{array}{l}\text { Aspergillus } \\
\text { fumigatus }\end{array}$ & CBS 120.53 & MH857125.1 & MH868658.1 & AY685156.1 & - & - \\
\hline 29 & $\begin{array}{l}\text { Aspergillus } \\
\text { fumigatus }\end{array}$ & CBS 114.55 & MH857399.1 & MH868939.1 & - & - & - \\
\hline 30 & $\begin{array}{l}\text { Aspergillus } \\
\text { niger }\end{array}$ & CBS 263.65 & MH858562.1 & MH870199.1 & - & - & - \\
\hline 31 & $\begin{array}{l}\text { Aspergillus } \\
\text { niger }\end{array}$ & CBS 105.47 & MH856174.1 & MH867698.1 & - & - & - \\
\hline 32 & $\begin{array}{l}\text { Aspergillus } \\
\text { niger }\end{array}$ & CBS 134.54 & MH857268.1 & MH868802.1 & - & - & - \\
\hline 33 & $\begin{array}{l}\text { Aspergillus } \\
\text { niger }\end{array}$ & ANG-1 & MH266204.1 & MH423841.1 & - & - & - \\
\hline 34 & $\begin{array}{l}\text { Aspergillus } \\
\text { niger }\end{array}$ & T4 & MG833314.1 & - & - & - & - \\
\hline 35 & $\begin{array}{l}\text { Aspergillus } \\
\text { niger }\end{array}$ & ATCC 9029 & KU729033.1 & KU729117.1 & JF450851.1 & - & - \\
\hline 36 & $\begin{array}{l}\text { Aspergillus } \\
\text { niger }\end{array}$ & CBS 117.36 & MH855726.1 & MH867238.1 & - & - & - \\
\hline 37 & $\begin{array}{l}\text { Aspergillus } \\
\text { niger }\end{array}$ & C5334 & AF109327.1 & AF109343.1 & - & - & - \\
\hline 38 & $\begin{array}{l}\text { Aspergillus } \\
\text { niger }\end{array}$ & CSR3 & MF187478.1 & MF187479.1 & - & - & - \\
\hline 39 & $\begin{array}{l}\text { Aspergillus } \\
\text { flavus }\end{array}$ & V5F-13 & HQ395774.1 & HQ395773.1 & - & - & - \\
\hline 40 & $\begin{array}{l}\text { Aspergillus } \\
\text { flavus }\end{array}$ & CHS1 & MF599088.1 & MF590165.1 & - & - & - \\
\hline 41 & $\begin{array}{l}\text { Aspergillus } \\
\text { tubingensis }\end{array}$ & CNU081066 & JF411067.1 & - & - & - & - \\
\hline 42 & $\begin{array}{l}\text { Aspergillus } \\
\text { niger }\end{array}$ & Z4 & MH892847.1 & - & - & - & - \\
\hline
\end{tabular}


Table 2

Comparison of characteristics of xylanases from other microorganisms

\begin{tabular}{|c|c|c|c|c|c|}
\hline Substrate & Microorganism & pH stability & $\begin{array}{l}\text { Temperature } \\
\text { stability }\end{array}$ & $\begin{array}{l}\text { Xylanase } \\
\text { activity }\end{array}$ & References \\
\hline \multirow[t]{3}{*}{$\begin{array}{l}3 \%(w / v) \text { Corn cob } \\
(\mathrm{SmF})\end{array}$} & $\begin{array}{l}\text { A. tubingensis } \\
\text { AUMS60 }\end{array}$ & $\begin{array}{l}>70 \%\left(96 \mathrm{~h} \text { at } 40^{\circ} \mathrm{C}\right) \text { at } \\
\mathrm{pH} 5.0-6.0\end{array}$ & $\begin{array}{l}\text { Stable at } 40^{\circ} \mathrm{C} \\
(120 \mathrm{~h})\end{array}$ & $32.29 \mathrm{U} \mathrm{ml}^{-1}$ & \multirow[t]{3}{*}{ This study } \\
\hline & & & $\begin{array}{l}>82 \%(4 \mathrm{~h} \text { at } \\
\left.50^{\circ} \mathrm{C}\right)\end{array}$ & & \\
\hline & $\begin{array}{l}\text { A. niger } \\
\text { AUMS64 }\end{array}$ & $\begin{array}{l}>70 \%\left(72 \mathrm{~h} \text { at } 40^{\circ} \mathrm{C}\right) \text { at } \\
\mathrm{pH} 5.0-6.0\end{array}$ & $\begin{array}{l}\text { Stable at } 40^{\circ} \mathrm{C} \\
(120 \mathrm{~h})>90 \% \\
\left(24 \mathrm{~h} \text { at } 50^{\circ} \mathrm{C}\right)\end{array}$ & $30.68 \mathrm{U} \mathrm{ml}^{-1}$ & \\
\hline \multirow{2}{*}{$\begin{array}{l}\text { Wheat bran } 0.5 \% \\
(\mathrm{w} / \mathrm{v})+\text { Corncob } \\
0.5 \%(\mathrm{w} / \mathrm{v})(\mathrm{SmF})\end{array}$} & $\begin{array}{l}\text { Aspergillus } \\
\text { niger }\end{array}$ & $\begin{array}{l}>95 \%\left(1 \mathrm{~h} \text { at } 0^{\circ} \mathrm{C}\right) \text { at } \\
\text { all } \mathrm{pH}\end{array}$ & $\begin{array}{l}85.72 \%(2 \mathrm{~h} \text { at } \\
\left.50^{\circ} \mathrm{C}\right)\end{array}$ & $10.5 \mathrm{U} \mathrm{ml}^{-1}$ & \multirow{2}{*}{$\begin{array}{l}\text { de Alencar } \\
\text { Guimaraes } \\
\text { et al. } 2013\end{array}$} \\
\hline & $\begin{array}{l}\text { Aspergillus } \\
\text { flavus }\end{array}$ & $\begin{array}{l}\text { decrease of } 10 \% \text { at } \mathrm{pH} \\
3.0-5.5 ; 100 \% \text { at } \\
\text { alkaline } \mathrm{pH}(1 \mathrm{~h} \text { at } \\
\left.0^{\circ} \mathrm{C}\right)\end{array}$ & $\begin{array}{l}\text { half-life }>75 \\
\text { min at } 50^{\circ} \mathrm{C}\end{array}$ & $11.92 \mathrm{U} \mathrm{ml}^{-1}$ & \\
\hline \multirow{2}{*}{$\begin{array}{l}3 \%(w / v) \text { Sugarcane } \\
\text { Bagasse }(\mathrm{SmF})\end{array}$} & $\begin{array}{l}\text { A. fumigatus } \\
\text { M51 }\end{array}$ & $\begin{array}{l}>70 \% \text { at pH } 4 \text { to } 9(24 \\
\left.\text { h at } 25^{\circ} \mathrm{C}\right)\end{array}$ & $\begin{array}{l}>60 \%(1 \mathrm{~h} \text { at } \\
\left.50^{\circ} \mathrm{C}\right)\end{array}$ & $35.6 \mathrm{U} \mathrm{ml}^{-1}$ & \multirow[t]{2}{*}{$\begin{array}{l}\text { Carvalho } \\
\text { et al. } 2015\end{array}$} \\
\hline & $\begin{array}{l}\text { A. fumigatus } \\
\mathrm{U} 2370\end{array}$ & & $\begin{array}{l}>61 \%(1 \mathrm{~h} \text { at } \\
\left.50^{\circ} \mathrm{C}\right)\end{array}$ & $28.5 \mathrm{U} \mathrm{ml}^{-1}$ & \\
\hline $\begin{array}{l}1 \%(\mathrm{w} / \mathrm{v}) \text { Birchwood } \\
\text { xylan (SmF) }\end{array}$ & $\begin{array}{l}\text { Aspergillus cf. } \\
\text { tubingensis } \\
\text { LAMAl } 31\end{array}$ & $\begin{array}{l}\text { Stable at pH } 3.6 \text { to } 7.0 \\
\left(24 \mathrm{~h} \text { at } 40^{\circ} \mathrm{C}\right)\end{array}$ & $\begin{array}{l}\text { Stable at } 40- \\
50^{\circ} \mathrm{C}(1 \mathrm{~h})\end{array}$ & $49.41 \mathrm{U} \mathrm{ml}^{-1}$ & $\begin{array}{l}\text { Dos } \\
\text { Santos et } \\
\text { al. } 2016\end{array}$ \\
\hline \multirow{2}{*}{$\begin{array}{l}0.1 \%(\mathrm{w} / \mathrm{v}) \\
\text { Beechwood xylan } \\
(\mathrm{SmF})\end{array}$} & $\begin{array}{l}\text { Aspergillus } \\
\text { niger }\end{array}$ & $\begin{array}{l}100 \% \text { at } \mathrm{pH} 2.0 \text { to } 5.0 \\
(1 \mathrm{~h})\end{array}$ & $\begin{array}{l}>79 \%(60 \mathrm{~min} \\
\left.\text { at } 37^{\circ} \mathrm{C}\right)\end{array}$ & $229 \mathrm{U}$ & \multirow[t]{2}{*}{$\begin{array}{l}\text { Uday et al. } \\
2017\end{array}$} \\
\hline & (KP874102.1) & & & & \\
\hline $\begin{array}{l}5 \%(w / v) \text { Wheat } \\
\text { straw }\end{array}$ & $\begin{array}{l}\text { A. niger } \\
\text { Gyx086 }\end{array}$ & Not available & $\begin{array}{l}>70 \% \text { at } 50^{\circ} \mathrm{C} \\
(72 \mathrm{~h})\end{array}$ & $\begin{array}{l}6.19 \pm 0.27 \mathrm{U} \\
\mathrm{ml}^{-1}\end{array}$ & $\begin{array}{l}\text { Wang et } \\
\text { al. } 2019\end{array}$ \\
\hline $\begin{array}{l}2.67 \%(\mathrm{w} / \mathrm{v}) \text { Wheat } \\
\text { bran }(\mathrm{SmF})\end{array}$ & A. terreus $\mathrm{S9}$ & $\begin{array}{l}>75 \% \text { at } \mathrm{pH} 6 \text { to } 10.0 \\
(90 \mathrm{~min})\end{array}$ & $\begin{array}{l}>75 \% \text { at } 60- \\
80^{\circ} \mathrm{C}(90 \mathrm{~min})\end{array}$ & $\begin{array}{l}116 \mathrm{U} \mathrm{ml}^{-1} \\
\text { (optimized) }\end{array}$ & $\begin{array}{l}\text { Sharma et } \\
\text { al. } 2018\end{array}$ \\
\hline $\begin{array}{l}3 \%(w / v) \text { Corn cob } \\
(\mathrm{SmF})\end{array}$ & $\begin{array}{l}\text { Aspergillus } \\
\text { flavus }\end{array}$ & $\begin{array}{l}>70 \% \text { at } \mathrm{pH} 3.5 \text { to } 10.5 \\
(30 \mathrm{~min})\end{array}$ & $\begin{array}{l}>90 \% \text { at } 50^{\circ} \mathrm{C} \\
(30 \mathrm{~min})\end{array}$ & $65 \mathrm{U} \mathrm{ml}^{-1}$ & $\begin{array}{l}\text { Chen et al. } \\
2019\end{array}$ \\
\hline $\begin{array}{l}1 \%(\mathrm{w} / \mathrm{v}) \text { Rice straw } \\
(\mathrm{SmF})\end{array}$ & $\begin{array}{l}\text { Aspergillus } \\
\text { oryzae LC1 }\end{array}$ & $\begin{array}{l}>84 \% \text { at } \mathrm{pH} 5(12 \mathrm{~h}) \\
>50 \% \text { at } \mathrm{pH} 7 \text { and } 9(8 \\
\text { h) }\end{array}$ & $\begin{array}{l}>50 \% \text { at } 50^{\circ} \mathrm{C} \\
(12 \mathrm{~h})\end{array}$ & $\begin{array}{l}1245 \mathrm{IU} \mathrm{ml}^{-1} \\
\text { (optimized) }\end{array}$ & $\begin{array}{l}\text { Bhardwaj } \\
\text { et al. } 2019\end{array}$ \\
\hline $\begin{array}{l}1 \%(\mathrm{w} / \mathrm{v}) \text { Paper } \\
\text { sludge, } 0.5 \%(\mathrm{w} / \mathrm{v}) \\
\text { sugarcane bagasse }\end{array}$ & $\begin{array}{l}\text { Aspergillus } \\
\text { clavatus } \\
\text { NRRL1 }\end{array}$ & $\begin{array}{l}>85 \% \text { at } \mathrm{pH} 3 \text { to } 8 \text { ( } 24 \\
\text { h) }\end{array}$ & $\begin{array}{l}80 \% \text { and } \\
100 \% \text { at } 50^{\circ} \mathrm{C} \\
(1 \mathrm{~h})\end{array}$ & Not available & $\begin{array}{l}\text { Pasin et al. } \\
2020\end{array}$ \\
\hline $\begin{array}{l}\text { Waste from flour } \\
\text { industry (SmF) }\end{array}$ & $\begin{array}{l}\text { Aspergillus } \\
\text { niger NRRL3 }\end{array}$ & $\begin{array}{l}\geq 80 \% \text { at } \mathrm{pH} 3 \text { to } 9 \text { (48 } \\
\left.\mathrm{h} \text { at } 20^{\circ} \mathrm{C}\right)\end{array}$ & $\begin{array}{l}>80 \% \text { at } 40^{\circ} \mathrm{C} \\
(96 \mathrm{~h})\end{array}$ & $\begin{array}{l}14.5 \mathrm{U} \mathrm{ml}^{-1} \\
\text { (After } \\
\text { optimization- } \\
138.3 \mathrm{U} \mathrm{ml}^{-1} \text { ) }\end{array}$ & $\begin{array}{l}\text { Taddia et } \\
\text { al. } 2020\end{array}$ \\
\hline
\end{tabular}

SmF: Submerged Fermentation, SSF: Solid state fermentation 
Table 3

Effect of selective metal ions and reagents on xylanase activity

\begin{tabular}{|c|c|c|c|}
\hline \multirow[t]{2}{*}{ Metal ions } & Concentration & AUMS60 & AUMS64 \\
\hline & $(\mathrm{mM})$ & Relative activity (\%) & Relative activity (\%) \\
\hline Control & 0 & 100 & 100 \\
\hline \multirow[t]{2}{*}{$\mathrm{NaCl}$} & 1 & 200.24 & 178.78 \\
\hline & 10 & 185.20 & 182.14 \\
\hline \multirow[t]{2}{*}{$\mathrm{KCl}$} & 1 & 196.34 & 179.71 \\
\hline & 10 & 198.36 & 179.33 \\
\hline \multirow[t]{2}{*}{$\mathrm{MgSO}_{4}$} & 1 & 125.69 & 124.83 \\
\hline & 10 & 124.31 & 89.20 \\
\hline \multirow[t]{2}{*}{$\mathrm{CuSO}_{4}$} & 1 & 87.39 & 110.85 \\
\hline & 10 & 1.82 & 1.52 \\
\hline \multirow[t]{2}{*}{ EDTA } & 1 & 73.63 & 71.58 \\
\hline & 10 & 79.89 & 56.82 \\
\hline \multirow[t]{2}{*}{$\mathrm{CaCl}_{2}$} & 1 & 115.35 & 125.80 \\
\hline & 10 & 65.34 & 57.82 \\
\hline \multirow[t]{2}{*}{$\mathrm{FeSO}_{4}$} & 1 & 89.50 & 82.43 \\
\hline & 10 & 124.83 & 116.51 \\
\hline \multirow[t]{2}{*}{ SDS* } & 1 & 74.53 & 22.61 \\
\hline & 10 & 74.37 & 38.71 \\
\hline
\end{tabular}

*Incubation for 15 min

Figures 

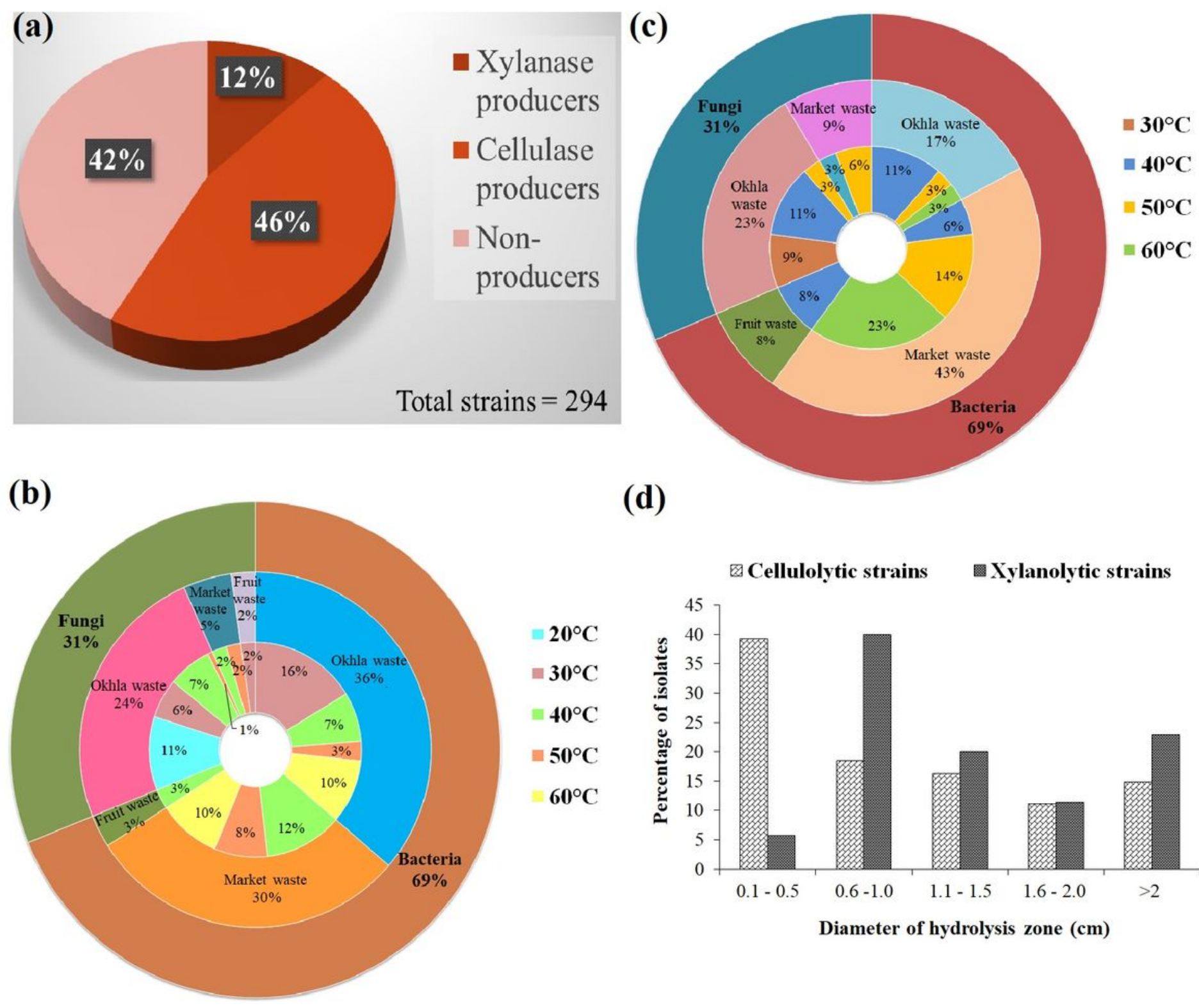

(d)

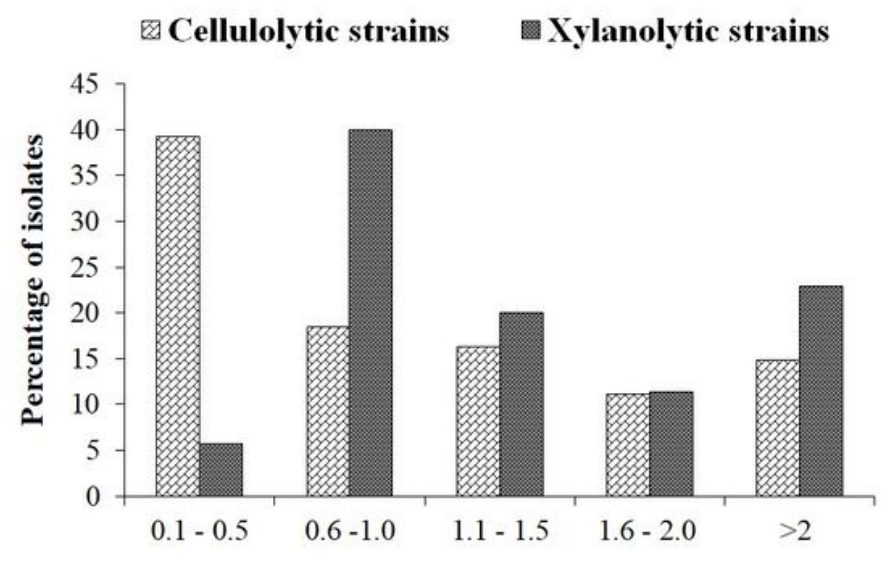

Diameter of hydrolysis zone $(\mathrm{cm})$

Figure 1

Distribution of microbial isolates according to their cellulolytic and xylanolytic activity. (a), percentage of cellulase and xylanase producers obtained after primary screening, from four different samples collected from different locations in Delhi and Noida, India (b), representation of cellulase positive strains ( $n=135)$ and (c), xylanase positive strains $(n=35)$ according to their location and incubation temperature (d), distribution of cellulolytic and xylanolytic strains according to their hydrolysis zone. 


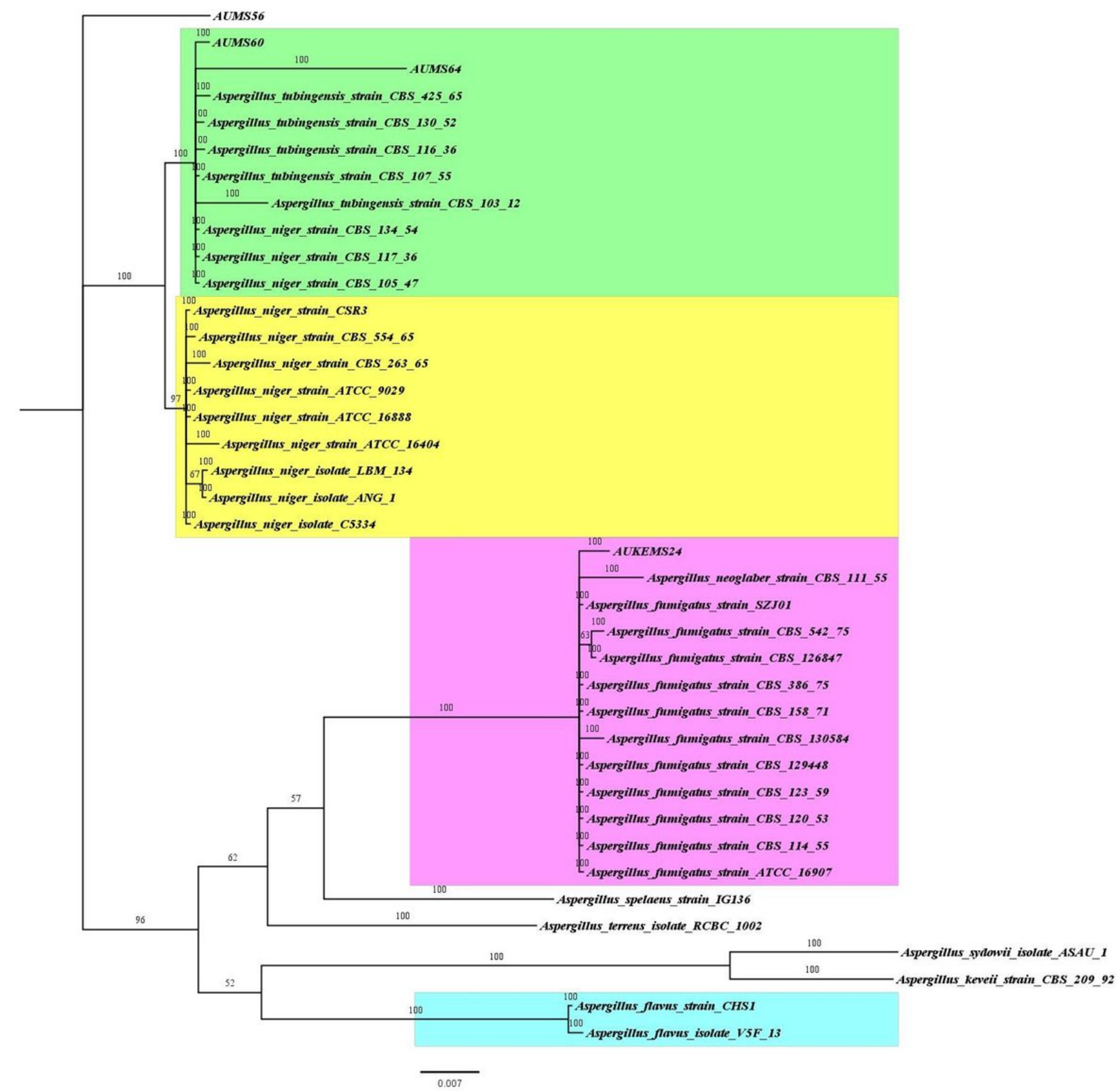

\section{Figure 2}

Phylogenetic tree derived from BI analysis based on the combined ITS and LSU rDNA data set, depicting the relationships of strains AUMS56, AUMS60, AUMS64 and AUKEMS24 with closely related taxa. Significant Bayesian posterior probability $(>50 \%)$ are shown on the respective branches. Bar, 0.007 changes per position. 


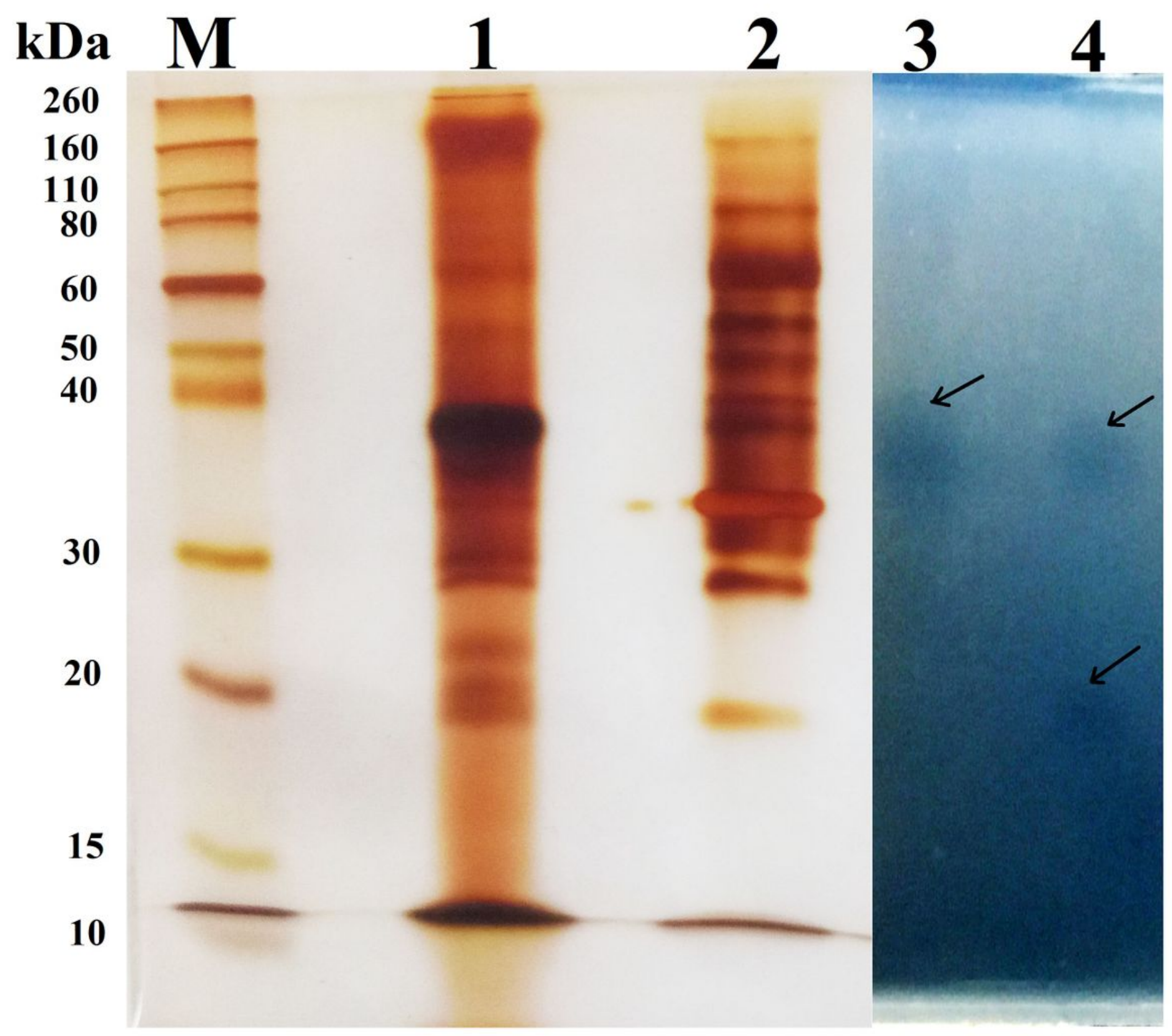

\section{Figure 3}

Zymogram analysis on $12 \%$ SDS- PAGE. Marker (M), partially purified enzymes from AUMS60 (Lane 1) and AUMS64 (Lane 2). Zymogram analysis of enzymes from AUMS60 (Lane 3) and AUMS64 (Lane 4). 
(a)

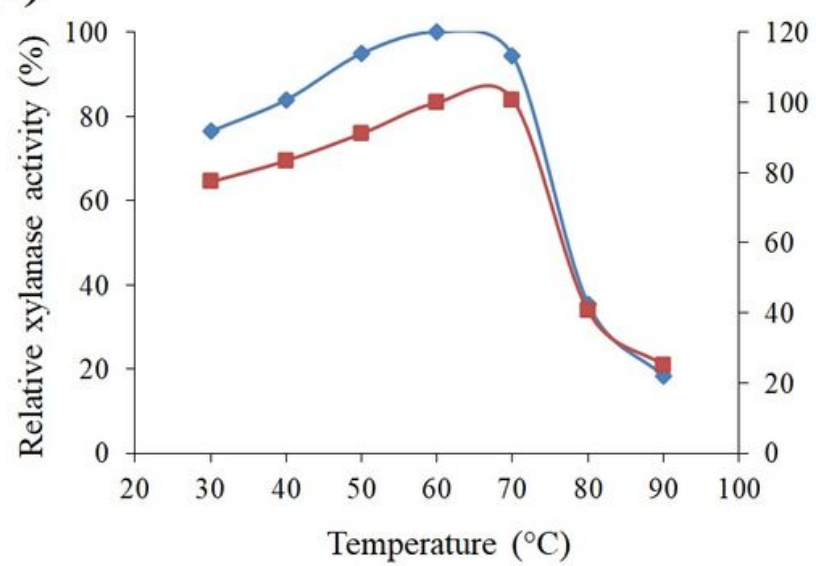

(c)

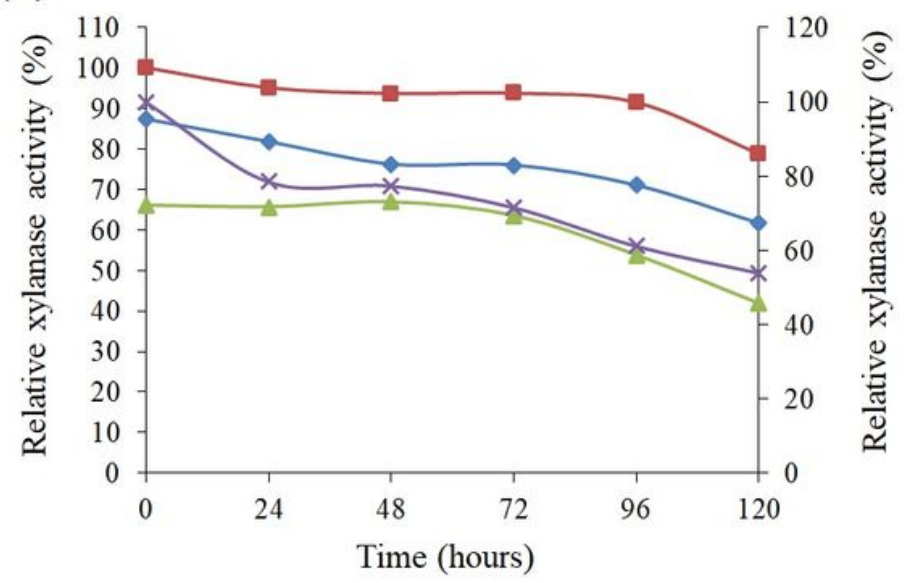

(b)

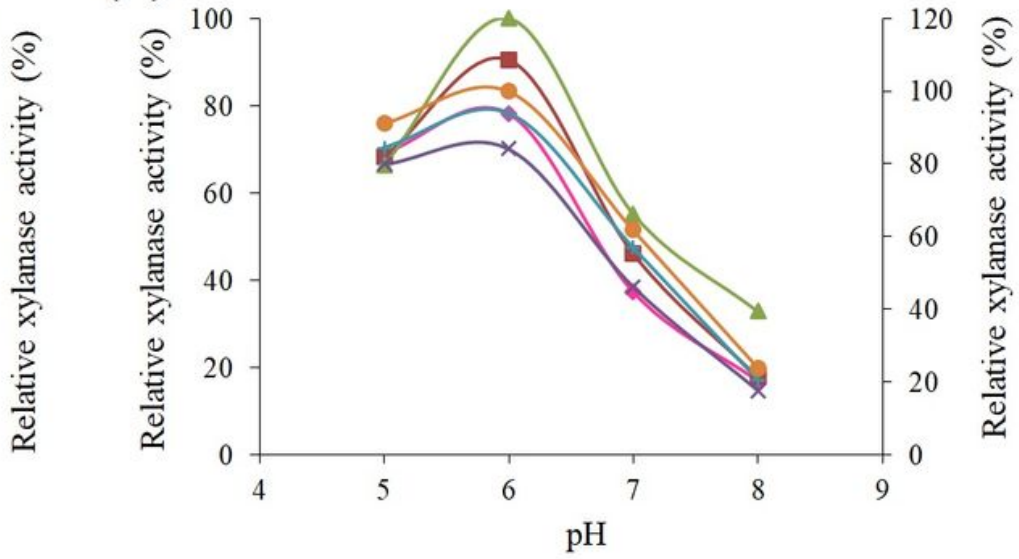

(d)

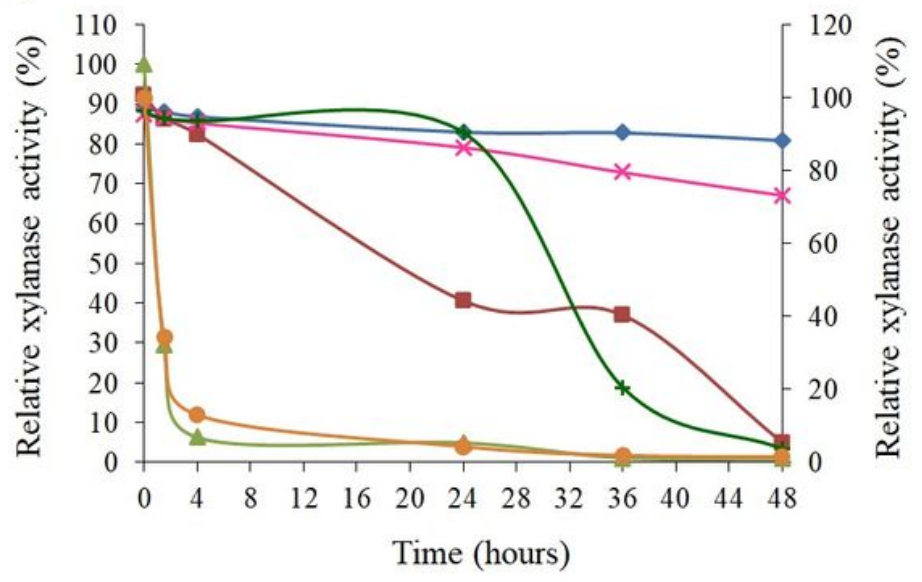

Figure 4

$\mathrm{pH}$ and temperature profiles of the partially purified xylanases from AUMS60 and AUMS64 (a), effect of temperature on activity ( $\$$ : AUMS60, $\square:$ AUMS64) and (d), thermostability determined at temperatures ranging from $30^{\circ} \mathrm{C}$ to $90^{\circ} \mathrm{C}$ in 50 $\mathrm{mM}$ sodium acetate buffer $(\mathrm{pH} 6)$; (b), effect of $\mathrm{pH}$ on activity [Xylanases from AUMS60 $\left(\checkmark: 40^{\circ} \mathrm{C}, \boldsymbol{\square}: 50^{\circ} \mathrm{C}, \boldsymbol{\Delta}: 60^{\circ} \mathrm{C}\right)$

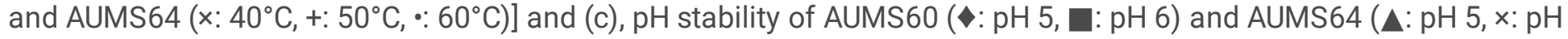
6) xylanases was evaluated at $40^{\circ} \mathrm{C}$ for $30 \mathrm{~min}$ in $50 \mathrm{mM}$ different buffers. Values represent the mean of tests conducted in triplicates $(n=3)$. 


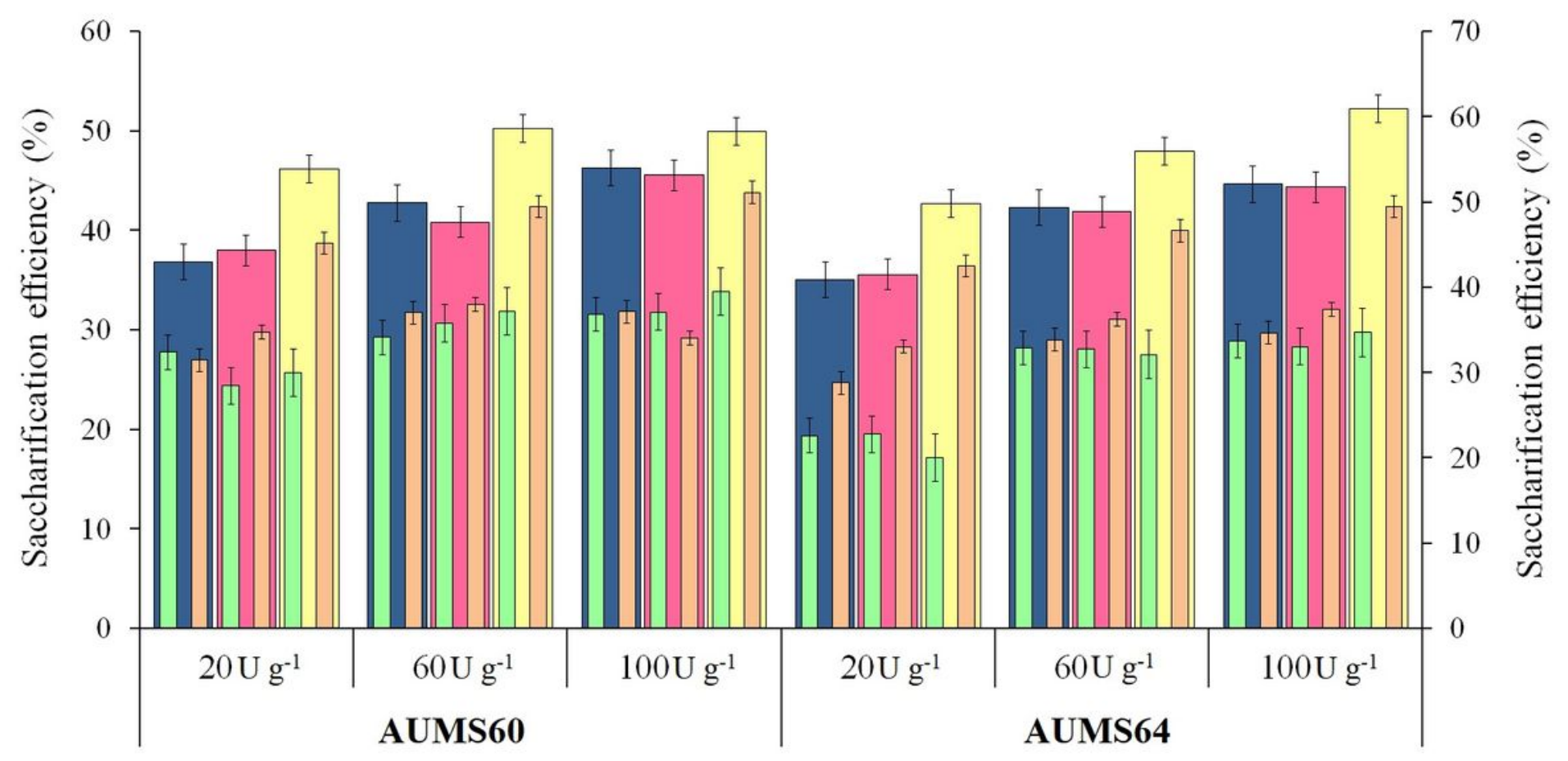

Figure 5

Saccharification efficiency of partially purified xylanase from AUMS60 and AUMS64 at different concentrations for varied time periods (green: 2 h, orange: 13 h, blue: 24 h/100 rpm, pink: 24 h/120 rpm, yellow: 24 h/140 rpm). Error bars represent the means $\pm S D(n=3)$.

\section{Supplementary Files}

This is a list of supplementary files associated with this preprint. Click to download.

- Graphicalabstract.tif

- SupplementaryInformationRevised.pdf 